\title{
The Russian Revolution in Sweden: Some Genetic and Genealogical Perspectives
}

Klas-Göran Karlsson (University of Lund)

$\mathrm{T}$ he upheavals in Petrograd in 1917 took place within Sweden's range and reach. For many Swedes, the events were ominously close. While Sweden - a neutral country - was not directly involved in the First World War, the conflict caused food shortages that led to strikes and hunger riots as far as the western shore of the Baltic Sea. Growing class antagonisms and the conservative Swedish political parties' persistent opposition to democracy were other driving forces behind popular discontent. No doubt, the situation in Petrograd provided demonstrators on the streets of Stockholm with inspiration. In the radical newspapers, the mounted military and police ordered out to confront them were called "Stockholm Cossacks." Sweden has never been closer to a social revolution than in the years 1917-1918.

In Swedish society, the Russian Revolution aroused contradictory feelings. Conservatives, most of them with sympathies for Russia's world war enemy, Germany, totally repudiated the March and November political changes in Petrograd, often depicting them as two stops on a downhill slope towards the decomposition of Russian society. The events in Russia confirmed the general historical lesson that revolutions devour their own children, a conservative newspaper warned. ${ }^{1}$ Meanwhile, broader liberal and social democratic groups in Sweden, positioned in favor of the Entente powers, welcomed the fall of the Romanov dynasty, and saw the rise to power of the Provisional Government in March 1917, as a promising development that could promote stabilization, freedom, and democracy in Russia, and indirectly also at home. However, when conditions in the Russian capital once more radicalized later in 1917, these groups sensed a growing threat and expressed their dissociation from the new Russian social and political trends.

1 “Krigströtthet," Sydsvenska Dagbladet Snällposten, November 12, 1917. 
For smaller radical groups in Sweden-many of them syndicalists who played an active role in Swedish demonstrations and riots, others belonging to the left wing of the Social Democratic Party-the news from Petrograd promised a better future for Russia, Sweden, and the world. As in most other European countries, an ideological rift between the reformist majority and the revolutionary minority within social democracy had grown stronger, and in May 1917, the radical opposition split from the Social Democratic Party to create the Social Democratic Left Party. After the Bolshevik coup in Petrograd in November, the antagonism between political groups increased. While for the reformists the Russian Revolution was not a model suitable for Sweden, they nevertheless saw it as an opportunity to put pressure on non-socialist groups to carry out political and social reforms-primarily universal suffrage and an eight-hour working day. The radicals, on the contrary, wanted Sweden to follow in the footsteps of the Russian revolutionaries and join the Bolsheviks' efforts to put an end to war and injustice.

In the Swedish case, however, the relation to Russia was not only ideological and political. There was a large group of people whose life and future was immediately and tangibly connected to the Russian Revolution. It consisted of Swedes who lived in Petrograd, many of whom were long-term inhabitants. Some of the first Swedish St. Petersburg inhabitants were prisoners from the Great Nordic War of 1700-1721. They had been forced to take an active part in the construction of Peter's new city. Some of them remained in Russia when they were set free after the 1721 Nystad peace agreement. It has been noted that in the prerevolutionary St. Petersburg period, when the Russian capital was "a huge sieve of humankind, a city of comers and goers" in the Baltic Sea area, Swedes were also more peacefully drawn to the metropolis. ${ }^{2}$ However, in contrast to the Finns and Estonians from the absolute vicinity of Russia who migrated to St. Petersburg in large numbers, Swedish emigration was more of an "urban long-distance transfer of small specialist groups," people mainly connected to Sweden's “genius” industries-Nobel, ASEA, L. M. Ericsson, Alfa-Laval, and the ball bearing industry SKF. ${ }^{3}$ In short, prerevolutionary Russia was an important economic market for Swedish trade and industry, especially in the economically expansive decades before the outbreak of the First World War. For the lives of the Swedes in Petrograd, generally a diminishing body that

2 See David Kirby, The Baltic World 1772-1993: Europe's Northern Periphery in an Age of Change (London and New York: Longman, 1995), 166.

3 Max Engman, Peterburgska vägar (Helsinki: Schildts, 1995), 30. 
in 1910 amounted to less than a thousand individuals, the Russian Revolution would have dramatic consequences. ${ }^{4}$

\section{A GENETIC HISTORICAL PERSPECTIVE}

For an historian, there are essentially two ways of analyzing the connections between the Russian Revolution and Sweden. The first perspective is geneticwhich means that it is prospective, oriented towards causes and effects, roots and developments. It focuses on how Sweden and Swedes influenced the Russian Revolution and revolutionaries, and on how the Russian Revolution in its turn made a more or less lasting impression on Swedish society, politics, and culture. As Matthew Rendle has recently argued, one can study the influences on as well as of the revolution, regarding it as both a coherent and entangled history. ${ }^{5}$

About the first aspect we know quite a lot thanks to Hans Björkegren, whose book Ryska posten provides us with an excellent, ideologically unbiased overview of the Russian revolutionaries' underground activities in the Nordic countries between 1906 and 1917. This was the period in which Sweden introduced the first Aliens' Act, followed by a passport and visa regime in 1918 . Björkegren demonstrates that "Red" postmen in Sweden served radical socialist circles in Russia with printed propaganda, letters, publication opportunities, weapons, refuge, escape routes, medicine, and money. He also provides evidence that Stockholm already swarmed with Russian revolutionaries in 1906, when the Russian Social Democrats held their secret fourth congress in the Swedish capital. This was more than a decade before the departure of the imperfectly sealed train that took Lenin from Switzerland to revolutionary Petrograd through the length of Sweden, from Trelleborg in the south to Haparanda in the north, and the third and final Zimmerwald antiwar conference that took place in Stockholm in September 1917. With the outbreak of the First World War in the summer of 1914, both Haparanda and Torneå, the latter on the Finnish side of the border between Sweden and Russian Finland, became what Björkegren calls "Europe's eye of the needle." This was the only open Russian mainland connection with the European continent, and large

4 For the numbers, see Natalia Iukhneva, "Shvedy v Peterburge v kontse XIX-nachale XX vekov," in Shvedy na beregakh Nevy. Sbornik statei, ed. Aleksandr Kobak et al. (Stockholm: Swedish Institute, 1998), 110-111. If Swedes from Finland are included, the number trebles.

5 Matthew Rendle, "Making Sense of 1917: Towards a Global History of the Russian Revolution,” Slavic Review 76, no. 3 (2017): 610. 
numbers of people, goods, and post suddenly started to cross the border. ${ }^{6}$ After reading Björkegren's book, there can be little doubt that the traditional notion of St. Petersburg as Russia's window towards the West must be supplemented with the idea that Sweden became another Russian European window in the turbulent period of revolution and war.

Aleksander Kan offers an important but less impartial addition to this history in his work on what he calls the "home Bolsheviks" of Sweden, identified as the radical socialists mentioned above. Straightforwardly, but without the results of a comparative analysis, he concludes that Swedish socialists and communists, "bold, talented, and colorful," had better contact with and insight into Russian and Soviet political developments than any other Europeans on the political left. ${ }^{7}$ Radical Swedes early realized the beneficial political role that Lenin would have, Kan argues, and they were so keen on his April 1917 theses on the need for a revolutionary war in Europe that they accepted and welcomed developments even before the Russian Bolsheviks did. ${ }^{8}$

Our knowledge of the second genetic aspect - that is, how the revolution influenced Sweden long after 1917-is more uneven and varied. This is not surprising, since such a transnational connection is hard to chisel out and analyze. Naturally, the more immediate repercussions are easier to mark than the long-term effects. Some general perspectives can nevertheless be suggested. As in many other European countries, the Russian Revolution probably triggered an interest among non-socialist politicians, even conservatives, frightened by Lev Trotskii's ominous idea of a world revolution, to force the pace of political and social reforms in order to avoid a repetition of the Russian case at home. As late as 1970, Hjalmar Mehr, a Social Democratic Stockholm politician whose father was a Russian, Jewish Menshevik who escaped the tsar's secret police, the Okhrana, by taking refuge in Sweden after the 1905 Revolution, confidently declared: "It is an historical fact that to a great extent, the emergence of democracy in Sweden was a result of the revolutions in Europe, in particular obviously of the Russian Revolution." 9

6 Quotation from Hans Björkegren, Ryska posten. De ryska revolutionärerna i Norden 19061917 (Stockholm: Bonniers, 1985), 130. See also 130-133.

7 Aleksander Kan, Hemmabolsjevikerna. Den svenska socialdemokratin, ryska bolsjeviker och mensjeviker under världskriget och revolutionsåren 1914-1920 (Stockholm: Carlssons, 2005), 22,45 .

8 Ibid., 116, 119.

9 Quoted from ibid., 23. 
However, whether the Swedish franchise reforms in the period 19181921 and the parliamentary ruling in favor of an eight-hour working day in 1919 can, or should be, mechanically attributed to events in Russia is doubtful. This apparently simple connection needs to be questioned. The end of the First World War, and the insistence on political rights as a "repayment" for the military contributions made by men and women all over Europe, was obviously another triggering event, even though Sweden did not take part in the war. Besides, the revolutionary connection tends to conceal the fact that the struggle for franchise reforms had been in progress for decades and had grown into a mass movement, not least among women. The only thing that stands clear is that Swedish political development after 1917 did not follow the Russian, nondemocratic road. In Sweden, a liberal government with several social democratic ministers - a government with a reformist political and social agendahad already taken office a few weeks before the Bolshevik November coup. It goes without saying that this Swedish government would have preferred the "bourgeois" Provisional Government of March 1917, to stay in power.

In general, the Bolshevik coup served to alienate most Swedes. To be sure, fear of Russia and Russians was not a new phenomenon in Sweden. For centuries, Russia and Russians had constituted the "significant other" for many Swedes. According to Gunnar Åselius, the years leading up to the First World War represented a culmination of a long history of Russophobia in leading Swedish circles. ${ }^{10}$ However, it would be wrong to attribute Swedish attitudes towards Russia and Russians solely to this tradition. Certainly, the Bolsheviks' threat of a world revolution generated a widespread fear, but when the Russian violence also "infected" Sweden, the fear increased. In 1919, three bodies of murdered Russians found in Lake Norrviken outside Stockholm affected Swedish opinion. It turned out that the brutal assassinations, carried out by a group of Russian refugees called Ryssligan (or the "Russian Ring"), led by the mystical Mohammed Beck Hadjetlaché who identified himself as a Cossack colonel, had connections to both the White and the Red side of the Russian Revolution. The motives are still obscure after all these years, but the murders were given a great deal of publicity in the Swedish press, and surely added to notions of an imminent "Russian danger" in Sweden. ${ }^{11}$

10 Gunnar Åselius, The "Russian Menace" to Sweden: The Belief System of a Small Power Security Élite in the Age of Imperialism (Stockholm: Almqvist \& Wiksell International, 1994), 7.

11 Svante Lundberg, Ryssligan. Flyktingarna från öst och morden i Bollstanäs 1919 (Lund: Nordic Academic Press, 2004). 
As discussed above, all the Swedish political parties, except for the radical socialists, were critical of the Bolshevik takeover. The division of the Social Democratic Party into two factions in the early months of 1917, and the formal split in May when the radicals founded the Social Democratic Left Party (renamed in 1921 the Swedish Communist Party), obviously paralleled the first part of the Russian Revolution, when the tsar was dethroned and the Provisional Government and the Soviets ruled in tandem. This raises the question whether the causes of the split can be attributed to events in Russia. Again, a simple answer should be avoided.

The reformists and the revolutionaries evaluated the Russian turmoil in diametrically different ways. The first group, members of the Social Democratic Party as well as individuals with social democratic ideals, unanimously condemned the Bolsheviks' destruction of Russia's young and fragile democracy. In their opinion, the dictatorship of the proletariat had turned into the dictatorship of the Bolshevik Party leadership. The term "revolution," used positively to denote the March events, from October increasingly implied a distortion of socialism. ${ }^{12}$ The Bolsheviks' use of Red Terror to stay in power was strongly rejected. Similarities to the derailment of the French Revolution, and its transformation into a terror regime, were frequently drawn. The Bolshevik leaders were depicted as "Russia's Jacobins."

As Håkan Blomqvist has proposed, Swedish social democrats, swollen with what he calls "evolutionary assurance," believed that socialism only could develop in a mature capitalist, industrial society, and therefore not in revolutionary Russia. There, socialism always risked becoming compromised before it could establish itself. If socialism was forced through, it was inevitable, social democrats held, that the Revolution would turn into a Bolshevik despotism that displayed "barbarian," "Asiatic," or even "tsarist Russian" traits. The Russian Revolution was not carried out by class-conscious workers (the ideal), but by peasant soldiers, and other marginalized social groups, who had reacted to injustice and misery spontaneously and in an excess of violence. With their revolution, the Bolsheviks challenged social democratic ideological DNA, as Blomqvist puts it. ${ }^{14} \mathrm{~A}$ contemporary observer working in Russia, the radical

12 Karin Jonsson, Fångna i begreppen? Revolution, tid och politik i svensk socialistisk press 19171924 (Huddinge: Södertörns högskola, 2017), 255-261.

13 Martin Alm, "Ryska revolutionen i svenska ögon 1917-1920," in Kristian Gerner and KlasGöran Karlsson, eds., Rysk spegel. Svenska berättelser om Sovjetunionen-och om Sverige (Lund: Nordic Academic Press, 2008), 124-126.

14 Håkan Blomqvist, "'Socialismus Asiaticus.' Bolsjevismen som orientaliskt hot för svenska socialdemokrater," in Håkan Blomqvist and Lars Ekdahl, eds., Kommunismen hot och löfte. 
socialist journalist and diplomat Nils Lindh, complained in the same vein in 1918 that the Bolsheviks were trying to lead history up the garden path ("draga historien vid näsan"). Just one year earlier, Lindh had still been confident that the Russian Revolution was "an honest attempt to catch up with and pass the comrades on a shortcut." 15

What is more, Blomqvist has contended that the social democratic attitudes to the Russian revolutionary experience not only departed from a Marxist, class-based understanding of the phases of historical development, but in some notable cases also from biological ideas of racial development. The idea was that Aryan, Germanic Swedes were superior in terms of organization and culture to less developed and more violent nations, such as Russia. According to Arthur Engberg, a leading Swedish social democrat but also a prominent antisemite, the Russian Revolution should be understood as Jewry's struggle to subordinate Russians to Jewish power and to conquer the world for the Jews. To be sure, Engberg was not alone among social democrats in Sweden and in other European countries to regard the Russian Revolution as an expression of a "Jewish spirit." 16

The second group — left-socialists and communists — defended Bolshevik ideas and politics at home. The Revolution was about their own political legitimacy, as well as the legitimacy of the new Russia. They praised the Bolsheviks for not only talking about socialism, but also having taken it seriously and acted to realize it. The Bolsheviks had fulfilled Marx's famous dictum that history should not only be understood but also changed.

In 1918, the revolutionary socialist agitator Kata Dalström, stated that "[h] umanity owes the greatest debt of gratitude to the Bolsheviks, the only ones who have demonstrated that they will, can, and dare to seriously set about realizing the 'social revolution.' That is, from the world of utopia move out onto the territory of reality the socialist dreams for which all of us who take socialism seriously had dreamt and longed." ${ }^{17}$ Narratives about revolutionary Russia had

Arbetarrörelsen i skuggan av Sovjetunionen 1917-1991 (Stockholm: Carlssons, 2002), 13-38.

15 Quoted from Peter Westlund, “'Sanningen’ om Sovjetunionen. Rysslandskännaren Nils Linds möte med öst åren 1917-1938," in Tom Olsson and Patrik Åker, eds., Jag har sett framtiden ... och den fungerar inte. Journalisterna och främlingarna i öst (Stockholm: Carlssons, 2002), 25, 30 .

16 Håkan Blomqvist, Nation, ras och civilisation i svensk arbetarrörelse före nazismen (Stockholm: Carlssons, 2006), 344-350.

17 Kata Dalström, Arbetarklassens Ryssland. Något om de sociala och kulturella reformerna i sovjetrepubliken (Stockholm: Fram, 1918), 20. 
severe limitations. Focusing on the war and the counterrevolutionary terror of the Whites, the Red Terror was reduced to a legitimate response to a precarious situation. At times, it entirely disappeared from radical debate. Thus, the execution of the Romanovs in the summer of 1918 was not recognized.

Paraphrasing the great prerevolutionary Russian historian Vasilii Kliuchevskii, Fredrik Ström (a Swedish left-socialist) posited that "the history of the Russian people is the history of its revolutions." 18 From 1919 to 1924, Ström served as a consul for the new Russian republic in Sweden. As the legation also served as the Comintern's Stockholm bureau, the consulate effectively assisted in facilitating Bolshevik colonization of new territories, including Sweden. Together with tens of thousands of other Western political and intellectual "pilgrims," Kata Dalström and several other left activists travelled to Petrograd to experience what they regarded as the start of the world communist revolution. Some of them kept their faith even after having seen the Russian reality and realizing that world revolution would not arise. Others, among them Dalström, gradually became more critical of the new Soviet power.

There was also movement in the other direction. Both Red and White Russians travelled to Sweden during the Revolution and in its aftermath, but for many of them Sweden became a transit country rather than a permanent place of residence. ${ }^{19}$ Swedes from the colony in St. Petersburg also took part in this migration. Most of them, alarmed by the hunger, turbulence, and violence, and fearful for their lives, left for Sweden in 1917-1918. When the Swedish embassy vacated Petrograd in December 1918, after a political decision to formally break off relations with the new Russia, those Swedes who remained lost all diplomatic protection. Swedish property was expropriated in the postrevolutionary nationalization process. A Russian inquiry commission in Sweden, officially established in 1919 to safeguard Swedish economic interests in Russia, was unsuccessful in its work. Thus, the Russian Revolution meant that human, economic, and political relations were abruptly cut off. In 1921, only 140 Swedes remained in Petrograd. ${ }^{20}$

18 Fredrik Ström, Ryska revolutionens historia i sammandrag (Stockholm: Ryska revolutionens historias förlag, 1924), 11.

19 See Anna Borovskaia, Russkaia emigratsiia v Shvetsii: Problemy vzaimootnoshenii diaspory, gosudarstva i obshchestva, 1918-1940 (St. Petersburg: Sankt-Peterburgskii gosudarstvennyi universitet, 2017).

20 Bengt Jangfeldt, Svenska vägar till St. Petersburg. Kapitel ur historien om svenskarna vid Nevans stränder (Stockholm: Wahlström \& Widstrand, 1998), 298. 
However, not all Swedes broke ties with Russia. Swedish businessmen, representing industrial and financial enterprises as well as state institutions, saw Russia as an interesting market with the potential to grow in spite of or even thanks to-the turbulent political and military conditions there. In May 1920, Sweden and Russia concluded an official agreement, named after the Russian commissar for trade and industry Leonid Krasin, for the export of Swedish products (such as locomotives and weapons) to Russia. These were badly needed in a country torn apart by civil war, and could be delivered now that the Entente powers had lifted their blockade in early 1920. The trade agreement also meant diplomatic recognition for the isolated state. For Sweden, it was just good business, and for individuals with a radical worldview an ideologically and politically charitable action. Apart from Fredrik Ström, an important economic intermediary was the "Red" Swedish banker Olof Aschberg, who had started his mediation activities by dispersing German money to Lenin and the Bolsheviks in 1917, and by helping them to melt confiscated gold in Stockholm. Aschberg and his bank had ended up on an Entente blacklist because of these activities, but he rapidly set up a new bank so that he could go on doing business with the Bolsheviks. As a token of his appreciation, Lenin gave the enterprising Aschberg exclusive rights to manage the Bolshevik government's financial affairs in Scandinavia and Germany. In 1922, the Swede founded Bolshevik Russia's first international bank, Roskombank. ${ }^{21}$

The Swedish agreement was not signed by Swedish state authorities but by an export organization representing major engineering companies. Nevertheless, it certainly benefitted from the fact that Sweden, for the first time in history, had a fully Social Democratic government. While the Social Democrats certainly did not cherish the Revolution and its revolutionaries, they did share an ideological fellowship with Bolshevik communism. Furthermore, a too unequivocally negative stance towards Soviet Russia would have undermined the legitimacy of some of the Social Democratic government's goals. Representatives on the Swedish side argued that trade with Soviet Russia served peace and stability. Attempts to defeat the Bolsheviks with military force had failed. The solution, then, was to establish economic relations with the isolated Bolshevik state, thereby changing Russia from within by reintegrating it into Europe. ${ }^{22}$ On 15 March 1924, the Swedish government recognized the

21 Sean McMeekin, The Russian Revolution, A New History (London: Profile, 2017), 336-342.

22 Helene Carlbäck-Isotalo, Att byta erkännande mot handel. Svensk-ryska handelsförbindelser 1921-1924 (Uppsala: Uppsala University, 1997), 50. 
Soviet Union, and on the same day an official trade agreement was signed by the two states.

What Aleksander Kan terms "socialist research" — that is, research on socialism carried out by social democrats, socialists, and communists-has focused less on concrete connections between Sweden and Russia than on the Revolution's influence on Sweden. The always difficult and highly politicized question is how the Russian Revolution impacted the Swedish labor movement and political parties on the left. Non-socialist historians propose that the left-socialist and communist parties rapidly went through a process of "bolshevization." They succumbed to Leninism, Comintern pressure, and Soviet supremacy in terms of organizational adjustment, ideological accommodation, and economic dependence. Contrary to Kan's insistence on a close relationship between Russian and Swedish socialists in this period, most other socialist historians hold that there was less Bolshevik influence on Swedish political development. Jan Bolin maintains that rather than following Bolshevik and Leninist ideas about creating a communist party-democratic centralism and strong party discipline, for example-left-socialists in Sweden placed importance on the logic of industrial capitalism that the party was initially meant to counteract. As a consequence, the Swedish political context (in particular, the lack of a sufficient grassroots movement) is considered more important than the international, Comintern dimension. ${ }^{23}$

Other socialist researchers propose that the outright anticommunism and anti-Bolshevism born out of a repudiation of the Russian Revolution is more important for Swedish political development. These writers argue that the Swedish labor movement, comprised of social democrats as well as supporters of the radical left, lost power by not following in the footsteps of the Russian revolutionaries, and by having been defeated by the anticommunists. ${ }^{24}$ The idea of a Swedish anticommunism has been described by Kristian Gerner as a myth. He has revealed the great variation, from the very beginning the Russian events, of reactions among Swedish observers - from apology to severe criticism, from appreciation of Russian women's emancipation to condemnation of the lack of democracy. Many critics of the revolution had a deep sympathy for Russian culture and took keen interest in everyday life in Russia and the early

23 Jan Bolin, Parti av ny typ? Skapandet av ett svenskt kommunistiskt parti 1917-1933 (Stockholm: Stockholm University, 2004), 133-197.

24 Werner Schmidt, Kommunismens rötter i första världskrigets historiska rum. En studie kring arbetarrörelsens historiska misslyckande (Stockholm and Stehag: Brutus Östlings Bokförlag Symposion, 1996), 11-12. 
Soviet Union, he maintains, but they were often less impressed by the Russian state's political development from 1917 onwards. $^{25}$

\section{A GENEALOGICAL HISTORICAL PERSPECTIVE}

The second historical perspective that can illuminate the relationship between Sweden and the Russian Revolution is genealogical. Contrary to the genetic approach, the genealogical perspective is self-consciously retrospective in that it starts out from the questions and problems that arise from our own historical moment. Such a perspective is not, however, completely spontaneous and arbitrary. When we turn to history, we follow in the footsteps of earlier representations of an event and forge separate instances of retrospection into a narrative path. Experience, memory, lessons learned, and the use of history are concepts related to a genealogical perspective, as are recognition, guilt, and legitimacy. Borderline events that are of special interest for our collective search for meaning in the past are: events that irrevocably changed the world we live in and that we tend to repeatedly term "turning-points"; "crossroads"; and "alternatives." The revolution in Petrograd in 1917 is one such borderline event. As noted by Frederick Corney in his book on the making of the Bolshevik Revolution in Russia and the Soviet Union in the decade after the revolution, the revolutionary narrative early on became a one of foundation and legitimation, useful not only for those with political power in the Kremlin, but also for broad sections of the Soviet population in search of existential and cultural orientation and sense-making. For many decades, the Great October Revolution was depicted as the peripeteia of not only Russian but world history. Furthermore, as Corney underlines, the revolutionary borderline event had a worldwide reach, for those who have cherished it or, quite the reverse, have regarded it as a serious threat against their societies. ${ }^{26}$

Unsurprisingly, the Russian Revolution has been interpreted, represented, and used as a borderline history in Swedish society and discourse ever since the end of the revolution. Sometimes it has been a cause of celebration or remembrance; at other times it has been used for comparison when similar events

25 Kristian Gerner, “Sovjetryssland med svenska ögon,” in Max Engman, ed., Väst möter öst. Norden och Ryssland genom historien (Stockholm: Carlssons, 1996), 307-333, Kristian Gerner, "Svenskars syn på Sovjetryssland: myten om antisovjetismen," in Klas-Göran Karlsson and Ulf Zander, eds., Östersjö eller Västerhav? Föreställningar om tid och rum $i$ Östersjöområdet (Karlskrona: Östersjöinstitutet, 2000), 33-46.

26 Frederick C. Corney, Telling October: Memory and the Making of the Bolshevik Revolution (Ithaca and London: Cornell University Press, 2004). 
have occurred. While the former are often, but not always, cultural manifestations, the latter are examples of a political appropriation of history in which borderline phenomena of the past are connected to what are perceived as urgent later problems. The approach to history strongly emphasizes continuity over time, and at the same time minimizes differences. Due to lack of space, only a few examples of this use of history will be presented here.

Generally, the "Swedish Bolshevik Revolution" has often been represented as either a promise or a threat. The Russian Revolution has often been used politically as a menacing event, and coupled with phenomena in contemporary life that allegedly resemble the revolution and the Bolshevik regime. Thus, in 1928 there was a "Cossack" election to the second chamber of the Swedish parliament. Rightist opponents to the Social Democrats were alarmed by the party's temporary electoral cooperation with the Communist Party, and with the thesis of its finance minister-Ernst Wigforss - that poverty shared is acceptable, while poverty in an unequal society is intolerable. The social democratic politics of increased taxation was called "outright Bolshevik," and on imaginative election posters a vote for the left was considered equated with a vote for Russian revolutionaries. On political posters, Cossacks-again represented both as violent instruments of power and as essentially Russian-were accompanied by language that emphasized the threat and called for political mobilization: "Your forefathers once saved Sweden from [the Danish king] Kristian the Tyrant. It is time to remake your great achievement. Any person who gives his or her vote to the worker's party votes for the overthrow of society and the introduction of Bolshevism. Save the Fatherland!" 27 In their newspapers, the radical left noted that the campaign "stimulated citizens' fear of the Russians." 28 The 1928 election brought out many more voters than usually, and was a great success for the political right. This indicates the strength of anticommunist attitudes among interwar Swedes.

Accusations of "bolshevization" have also tended to accompany the great economic debates of the postwar era. In 1948, as a response to war experiences and the labor movement's postwar program, and in a heated election campaign that ended the Burgfried of the war years, argument raged about the desirability of a planned economy in Sweden. Those against the idea of

27 Political poster, quoted in Rune Johansson, "Samlande, lättförståelig och eggande? Kosacker, kultur och kvinnor i valaffischer från 1928," in Lars M. Andersson, Lars Berggren, and Ulf Zander, eds., Mer än tusen ord. Bilden och de historiska vetenskaperna (Lund: Nordic Academic Press, 2001), 234.

28 Ibid., 223-243. 
an economy in which the state would have an increased influence on the planning, organization, and production of Swedish industry, contended that the radical politics of socialization and its concomitant displacement of individual, liberal freedom in Swedish society would inevitably lead to an autocratic state. One non-socialist Swedish newspaper was worried that Sweden was bound to succumb to "a radical transformation of our present economic system." 29 There were times when Swedish social democracy was anxious to draw a clear boundary with the Bolshevik system in Russia, wrote another, but with "the Red Army's successes in Eastern Europe" the line between social democracy and communism has now been blurred. Historical perspectives were, as in the Cossack election case, used to bring postwar Sweden closer to communist and totalitarian Russia: "The Swedish people has not carried heavy individual and economic burdens on its back for six years simply to allow its freedom to be choked by the kind of state that, while it starts with 'economic democracy' and 'planned economy,' ends with totalitarian rule over spiritual and material life." At that time, both sides complained about the others" "alarmist propaganda."30

In 1976, the Labor Movement For Employee Funds proposed placing some of the profits made by large companies into a public trust. Their further recommendation that wage earners dominate company boards rankled many non-socialist voters. Even in this case, more or less explicit comparisons between Swedish fondsocialism and the nationalizations imposed in communist Russia were made to mobilize non-socialist opinion. Whereas social democrats tied their policy of economic democracy to Swedes' needs and demands for increased participation in, and influence on, working conditions, non-socialists insisted that economic democracy would transform Sweden into an Eastern European Bloc state. The non-socialist argument was obviously successful, and the Social Democratic Party was punished by voters, and in 1976 there was an epoch-making change of government. From 4 October 1983, demonstrators marched against fondsocialism. Jokingly, but also with some seriousness, the demonstrations, organized by worried and angry representatives of small business owners, were called the "October Revolution."

These genealogical patterns have not been consistent and continuous. As mentioned, the Russian Revolution has been met by a traditional blend of promise and fear, but also with a certain lack of interest in the last few decades. In history textbooks, a particular chronological structure has been established.

29 Ibid.

30 For the debate, see Leif Lewin, Planhushållningsdebatten (Stockholm: Almqvist \& Wiksell, 1967), 241-262. 
Until the Second World War, the narrative of the Russian Revolution was generally negative and critical, underscoring the lack of democracy and the abundance of violence that followed. The events that caused the greatest disruptions in twentieth-century Europe were, one textbook stated, the reparations imposed on Germany after the First World War and the Russian Revolution. There was much empathy for the victims of the revolution, the Romanovs, and the tsarist elite. Fear of a communist world revolution was conspicuous: "The Bolsheviks in Russia try to find supporters in other countries and work single-mindedly to light the revolutionary fire all over the world." The word "Bolshevik," according to same leading interwar textbook, "is derived from a word that means 'more'; because they were more destructive and subversive than the moderate socialists." 31

After the war, with a longer temporal distance and a victorious Soviet Union, schoolbook images of the Russian Revolution quickly changed. Its violent aspects faded away, the image of Lenin became more positive, and the economic and social dimensions of the Revolution received more appreciative attention. Furthermore, the tsarist order was presented in a much darker light. In the radical 1960s and 1970s, these revisions sometimes turned into apologetic narratives, reminiscent of the ideas of the radical socialists immediately after the revolution. ${ }^{32}$

These pre- and post-1945 narratives roughly correspond to the two approaches that have dominated scholarly historiography on the Russian Revolution. They are known the "Pipes" and the "Fitzpatrick" narratives, named after two renowned historians with radically differing interpretations of the Petrograd events. ${ }^{33}$ The first tells the story of a failed, and evil, revolution that was hijacked by ideological fanatics willing to override all human considerations to create a new, utopian society that soon became dystopian. The second, on the other hand, regards 1917 as a popular revolution that brought an end to repression and injustice in Russia, and promised a better future for the oppressed of the world.

The textbook narratives had their counterparts among interwar intellectuals and travelers to the new Russia. Some of these people were "fellow

31 J. R. Pallin and Gustaf Jacobson, Lärobok $i$ allmän historia för realskolan (Stockholm: Norstedts, 1925), 209.

32 For a conspicuous example, see Håkan Olsson, Historia i världen. Studium 80 (Nacka: Esselte, 1981), 152-153. For a general analysis, see Klas-Göran Karlsson, ”Ryska revolutionen i svenska historieläroböcker 1920-1985," Historielärarnas Förenings Årsskrift (1985/1986): 44-59.

33 See Richard Pipes, The Russian Revolution, 1899-1919 (London: Harvill, 1990), and Sheila Fitzpatrick, The Russian Revolution (Oxford: Oxford University Press, 1982). 
travelers," while others took up critical attitudes to the new rulers. In 1925, looking back on the Bolshevik Revolution, one of the most qualified observers, the liberal Copenhagen professor of Slavic languages Anton Karlgren, noted the existence of two Russian revolutions: the first was a genuine, but brief, "dictatorship of the proletariat," useful "as long as the task was to crush the old Russia into bits and pieces;" 34 the other was conducted by the party élite on the principle of top-down centralism. Karlgren's conclusion was that the two revolutions seldom met. The representatives of the first revolution did not participate in social and political life, and they were strictly controlled by the communist leaders who has reaped the fruits of the revolution. ${ }^{35}$

In Swedish scholarly discourse, the Russian Revolution is not a mainstream area of study. Whether this is due to a lack of linguistic skills, cultural distance, fear of the politicized nature of the topic, or something else is unclear. Swedish historians normally write about Swedish history in Swedish, which means that most scholarship on the subject deals only with aspects of the Swedish perception or reception of the events of $1917 .{ }^{36}$ Jubilees are always good opportunities to remember borderline historical events. In 1967, in a radical political climate, the Marxist Gunnar Gunnarson published a revolutionary chronicle of the events that had unfolded fifty years earlier. He proudly declared: "The old, 'holy' Russia made room for something new, something no one had ever seen in history - a society built on the joint ownership of the means of production and based on the "dictatorship of the proletariat" proclaimed by Lenin."37 A few biographies of Lenin, ranging from Stefan Lindgren's hagiographic portrait to Kjell Albin Abrahamson's deeply anti-Leninist Great Was Lenin ... : A Mass Murderer and His Coup, were published quite recently. ${ }^{38}$

In Sweden, the centenary of the Russian Revolution roused neither negative interpretations of the past nor optimistic expectations for the future. The Petrograd events of 1917 have lost their meaning as borderline history, and have been laid to rest by most Swedish historians. An historian should not indulge in rigid interpretations, but there are many indications that what the

34 Anton Karlgren, Bolsjevikernas Ryssland (Stockholm: Albert Bonniers Förlag, 1925), 10.

35 Ibid., 9-21.

36 A notable exception is my own doctoral thesis on the objectives of history teaching in Russia and the Soviet Union 1900-1940: Historieundervisning i klassisk ram. En didaktisk studie av historieämnets målfrågor i den ryska och sovjetiska skolan 1900-1940 (Lund: Dialogos, 1987).

37 Gunnar Gunnarson, Ryssland 1917. En revolutionskrönika månad för månad (Stockholm: Tiden, 1967), 9-11.

38 Stefan Lindgren, Lenin (Stockholm: Fischer, 1999), Kjell-Albin Abrahamson, Stor var Lenin ... : En massmördare och hans statskupp (Stockholm: Hjalmarsson \& Högberg, 2017). 
American communist John Reed called the Ten days that Shook the World have stopped shaking a hundred years later. ${ }^{39}$

\section{Bibliography}

Abrahamson, Kjell Albin. Stor var Lenin... : En massmördare och hans statskupp. Stockholm: Hjalmarson \& Högberg, 2017.

Alm, Martin. "Ryska revolutionen i svenska ögon 1917-1920.” In Rysk spegel. Svenska berättelser om Sovjetunionen - och om oss, edited by Kristian Gerner and Klas-Göran Karlsson, 113-149. Lund: Nordic Academic Press, 2008.

Björkegren, Hans. Ryska posten. De ryska revolutionärerna i Norden 1906-1917. Stockholm: Bonniers, 1985.

Blomqvist, Håkan. Nation, ras och civilisation i svensk arbetarrörelse före nazismen. Stockholm: Carlssons, 2006.

“'Socialismus Asiaticus.' Bolsjevismen som orientaliskt hot för svenska socialdemokrater." In Kommunismen hot och löfte. Arbetarrörelsen i skuggan av Sovjetunionen 1917-1991, edited by Håkan Blomqvist and Lars Ekdahl, 13-38. Stockholm: Carlssons, 2002.

Bolin, Jan. Parti av ny typ? Skapandet av ett svenskt kommunistiskt parti 1917-1933. Stockholm: Almqvist \& Wiksell International, 2004.

Borovskaia, Anna. Russkaia emigratsiia v Shvetsii: problemy vzaimootnoshenii diaspory, gosudarstva i obshchestva (1918-1940). St. Petersburg: Sankt-Peterburgskii gosudarstvennyi universitet, 2017.

Carlbäck-Isotalo, Helene. Att byta erkännande mot handel. Svensk-ryska förhandlingar 19211924. Uppsala: Uppsala universitet, 1997.

Corney, Frederick C. Telling October. Memory and the Making of the Bolshevik Revolution. Ithaca: Cornell University Press, 2004.

Dalström, Kata. Arbetarklassens Ryssland. Något om de sociala och kulturella reformerna i sovjetrepubliken. Stockholm: Fram, 1918.

Fitzpatrick, Sheila. The Russian Revolution. Oxford: Oxford University Press, 1982.

Gerner, Kristian. “Sovjetryssland med svenska ögon.” In Väst möter öst. Norden och Ryssland genom historien, edited by Max Engman, 307-333. Stockholm: Carlssons. 1996.

. "Svenskars syn på Sovjetryssland: myten om antisovjetismen." In Östersjö eller Västerhav? Föreställningar om tid och rum i Östersjöområdet, edited by Klas-Göran Karlsson and Ulf Zander, 34-46. Karlskrona: Östersjöinstitutet, 2000.

Gunnarson, Gunnar. Ryssland 1917. En revolutionskrönika månad för månad. Stockholm: Tidens Förlag, 1967.

Jangfeldt, Bengt. Svenska vägar till St. Petersburg. Kapitel ur historien om svenskarna vid Nevans stränder. Stockholm: Wahlström \& Widstrand, 1998.

39 John Reed, Ten Days that Shook the World (Auckland: The Floating Press, 1919). 
Johansson, Rune. "Samlande, lättförståelig och eggande? Kosacker, kultur och kvinnor i valaffischer från 1928.” In Mer än tusen ord. Bilden och de historiska vetenskaperna, edited by Lars M Andersson, Lars Berggren, and Ulf Zander, 223-243. Lund: Nordic Academic Press, 2001.

Jonsson, Karin. Fångna i begreppen? Revolution, tid och politik i svensk socialistisk press 1917-1924. Huddinge: Södertörns högskola, 2017.

Kan, Aleksander. Hemmabolsjevikerna. Den svenska socialdemokratin, ryska bolsjeviker och mensjeviker under världskriget och revolutionsåren 1914-1920. Stockholm: Carlssons, 2005.

Karlgren, Anton. Bolsjevikernas Ryssland. Stockholm: Albert Bonniers Förlag, 1925.

Karlsson, Klas-Göran. Historieundervisning i klassisk ram. En didaktisk studie av historieämnets målfrågor i den ryska och sovjetiska skolan 1900-1940. Lund: Dialogos, 1987.

Karlsson, Klas-Göran. "Oktoberrevolutionen i svenska läroböcker 1920-1985." Historielärarnas Förenings Årsskrift (1985-1986): 44-59.

Kirby, David. The Baltic World 1772-1993: Europe's Northern Periphery in an Age of Change. London and New York: Longman, 1995.

“Krigströtthet." Sydsvenska Dagbladet Snällposten. November 12, 1917.

Lindgren, Stefan. Lenin. Stockholm: Fischer, 1999.

Lewin, Leif. Planhushållningsdebatten. Stockholm: Almqvist \& Wiksell, 1967.

Lundberg, Svante. Ryssligan. Flyktingarna från öst och morden i Bollstanäs 1919. Lund: Nordic Academic Press, 2004.

McMeekin, Sean. The Russian Revolution, A New History. London: Profile, 2017.

Pipes, Richard. The Russian Revolution, 1899-1919. London: Harvill, 1990.

Rendle, Matthew. "Making Sense of 1917: Towards a Global History of the Russian Revolution." Soviet Studies 76, no. 3 (2017): 610-618.

Schmidt, Werner. Kommunismens rötter i första världskrigets historiska rum. En studie kring arbetarrörelsens historiska misslyckande. Stockholm and Stehag: Brutus Östlings Bokförlag Symposion, 1996.

Ström, Fredrik. Ryska revolutionens historia i sammandrag. Stockholm: Ryska revolutionens historias förlag, n.d.

Westlund, Peter. "'Sanningen' om Sovjetunionen. Rysslandskännaren Nils Lindhs möte med öst åren 1917-1938.” In Jag har sett framtiden ... och den fungerar inte. Journalisterna och främlingarna i öst, edited by Tom Olsson and Patrik Åker, 20-55. Stockholm: Carlssons, 2002.

Åselius, Gunnar. The "Russian Menace" to Sweden: The Belief System of a Small Power Security Élite in the Age of Imperialism. Stockholm: Almqvist \& Wiksell International, 1994. 